\title{
ALONG-STRIKE VARIATIONS IN THE HELLENIDE- ANATOLIDE OROGEN: A TALE OF DIFFERENT LITHOSPHERES AND CONSEQUENCES
}

\author{
Ring U. ${ }^{1}$, Gessner K. ${ }^{2}$, Thomson S. ${ }^{3}$ and Markwitz V. ${ }^{2}$ \\ ${ }^{1}$ Department of Geological Sciences, Stockholm University, Stockholm, Sweden, uwe.ring@geo.su.se \\ ${ }^{2}$ Centre for Exploration Targeting, The University of Western Australia, M006, 35 Stirling Highway, Crawley \\ 6009, Australia \\ ${ }^{3}$ Department of Geosciences, University of Arizona, Gould-Simpson Building, 1040 E. 4th St., Tucson, AZ \\ 85721-0077, USA;
}

\begin{abstract}
Structure and exhumation history of the Hellenide-Anatolide Orogen in the Aegean Sea region and the adjacent Anatolian peninsula is controlled by along-strike variations of pre-Alpine palaeogeography. In the Hellenides, Mesozoic extension created ribbon-like continental fragments of thinned and dense lithosphere that pinch out eastwards. In the east, the relatively large Anatolide microcontinent mostly escaped Mesozoic extension and lithospheric thinning, presumably because it had a distinctly different, thicker and more depleted lithosphere. In the Aegean transect these alongstrike differences in lithosphere structure ultimately resulted in sustained highpressure metamorphism followed by progressive slab retreat since about $60 \mathrm{Ma}$. Further east, collision of the Anatolide microcontinent at about $42 \mathrm{Ma}$ formed a south verging greenschist-facies thrust-and-fold belt. Pronounced slab retreat in the Aegean forced differential extension resulting in a broad sinistral wrench corridor that started to from at 24-23 Ma. Since then, extension in both regions mainly controlled denudation. This review highlights how differences in pre-orogenic architecture control lithospheric thickening and the subsequent exhumation of high-pressure rocks, and how large-scale continental extension evolves.
\end{abstract}

Key words: Hellenides, Anatolides, lithospheric tear.

\section{Introduction}

Much of the conceptual understanding of the development of orogens is still largely based on the assumption of cylindricity, i.e. the premise of structural continuity along strike. However, lithospheric architecture and strain in orogens usually vary substantially, both across and along strike. The causes for along-strike variations are likely to differ in individual orogenic belts, but preorogenic paleogeography, continental architecture, the nature of the accreting lithospheric fragments and kinematic/geometric variations at the lithospheric scale potentially play an important role. Along-strike changes in orogens have a profound impact on how major orogenic processes proceed in time and especially in space along strike.

Conceptual and numerical models of generic and regionally specific orogens suggest that deformation is mainly driven by external forcing by the sinking slab (Royden, 1993), but also internally, 
by gravitational instabilities within the thermally weakened overriding plate (Houseman et al., 1981). Here we present an example of along-strike variations in the Hellenide-Anatolide Orogen in the eastern Mediterranean showing that regions controlled by slab sinking can occur in close proximity to region whose development is controlled by delamination.

Presently the transition from the Hellenide Orogen of Greece and the Anatolide Belt of west Turkey (aka Menderes Massif) is marked by a drastic change in topography, i.e. the changeover from the Aegean Sea basin into the Turkish mainland (Figure 1) (Gessner et al., 2013). Recent fieldbased studies show that differences in pre-orogenic paleogeography caused the Hellenide Orogen of eastern Greece and the Anatolide Belt of western Turkey to evolve in different ways (Gessner et al., 2011). We believe that better identification and understanding of those differences will potentially clarify how eastern Mediterranean subduction zones evolved, how pre-orogenic architecture and lithospheric structure controls crustal thickening, the exhumation of high-pressure rocks, and especially how large-scale continental extension evolves.

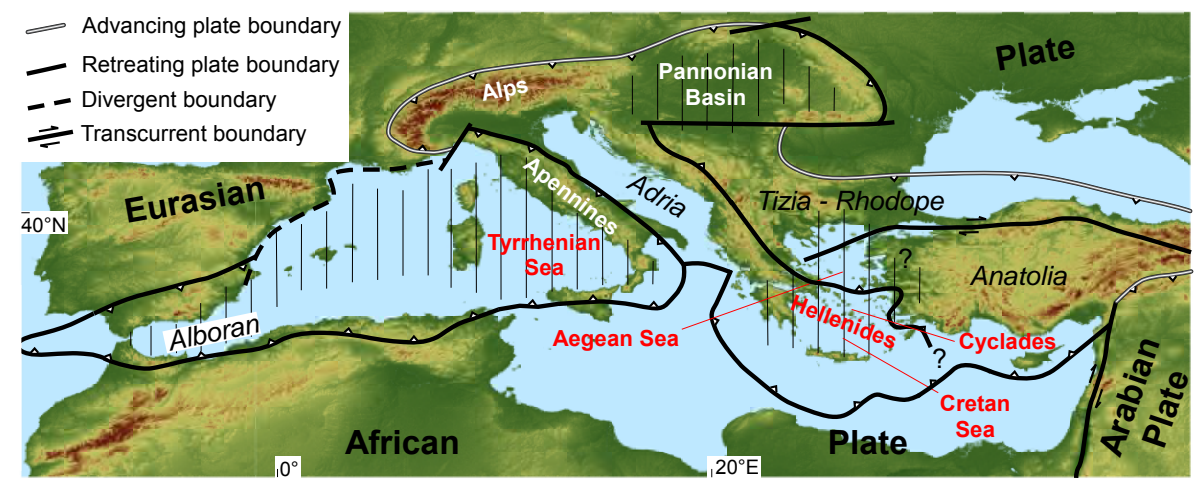

Figure 1 - Highly simplified tectonic map of the Mediterranean plate boundary zone showing retreating, advancing, and major transcurrent plate boundaries (barbs on overriding plate). Shown are the three major plates (Eurasia, Africa, Arabia) and, schematically, microplates between the three major plates; these microplates are currently forming (e.g., Anatolia) or have been amalgamated to Eurasia in the past (e.g., Adria). Vertical lines indicate highly extended regions above retreating plate boundaries (after Ring et al., 2010).

\section{Setting}

\subsection{Paleogeography}

In the eastern Mediterranean, the Adriatic plate (Adria for short) pinches out towards the east. Figure 2 shows a paleogeographic reconstruction of the area (Gessner et al., 2001a). The eastern edge of Adria is characterized by ribbons of normal thickness continental crust and intervening parts of highly stretched and thinned crust which were, at least in part, oceanic (Robertson et al., 1991). The stretching and oceanization resulted from Mesozoic rifting processes in and before the early Cretaceous when Adria was the northern part of the African plate. These rifting processes ultimately separated Adria from Africa. Further east, Neotethys broadened (Robertson et al., 1991) and a number of continental blocks that rifted off Gondwana in the Jurassic and Cretaceous occur. In the eastern Mediterranean the continental block east of Adria was Anatolia (Figure 2). Below we outline major difference in lithospheric architecture between Adria (Aegean Sea region) and Anatolia (west Turkey).

\subsection{Regional Structure}

The Hellenide orogen of Greece and the Anatolide belt of western Turkey form an arcuate orogen 


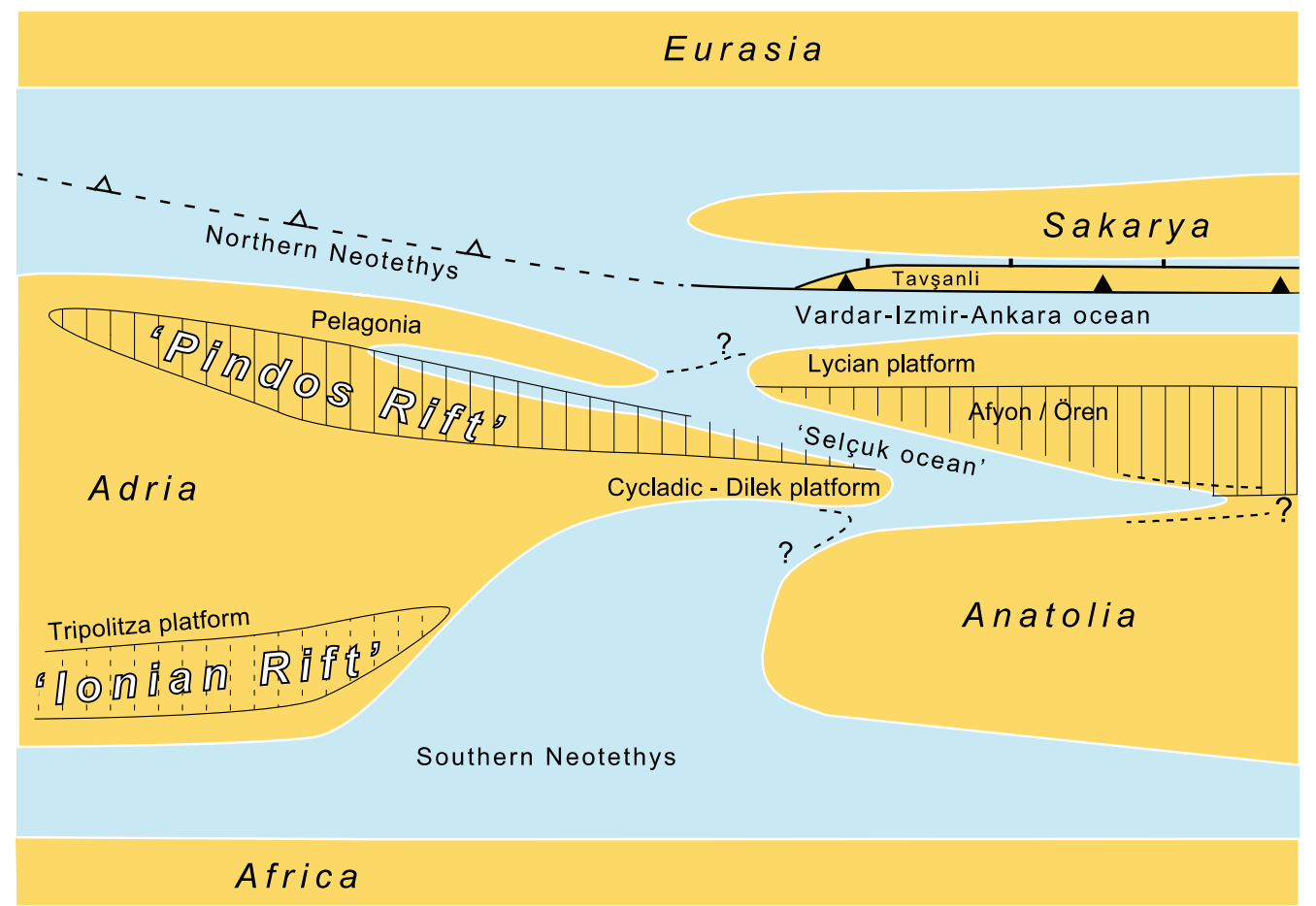

Figure 2 - Paleotectonic reconstruction of the eastern Mediterranean (after Gessner et al., 2013).

to the north of the present-day active Hellenic margin which marks the site of northnortheastwards underthrusting of the African plate underneath Europe. Both regions consist of a nappe stack, which is fringed to the north by the Late Cretaceous to Paleogene Vardar-İzmir-Ankara suture (Figure 3) zone, referred to as suture zone in the remainder of the paper. This Neotethyan suture separated units of Eurasian affinity in the north (Rhodope and Sarkaya zones) from Adria-derived continental units in Greece and a Gondwana-derived continental fragment in west Turkey (Anatolia) to the south. We will use this suture zone as our marker and describe the tectonic units below it from the Hellenide Orogen in the Aegean Sea region and the Anatolide belt in west Turkey. We will show that the nappe piles in both regions are characterized by nappes with different lithologies, PTt history and have different crustal architectures (Gessner et al., 2013).

\subsubsection{Hellenide Orogen}

In the Aegean Sea transect, the general architecture of the nappe pile is commonly north dipping. The uppermost nappe, referred to as Upper Unit, consists of the composite Cycladic ophiolite nappe made up of non-metamorphosed to greenschist-facies ophiolitic rocks and tectonically intercalated low-pressure metamorphic rocks of Late Cretaceous age (Jolivet et al., 1996). We regard this Upper Unit as part of the suture zone. The basement-cover sequence of the Pelagonian Zone occurs below the suture zone. Only parts of the Pelagonian Zone show evidence for Late Cretaceous high-pressure metamorphism, whereas other parts of the Pelagonian Zone escaped metamorphism (Jolivet and Brun, 2010). The Pelagonian Zone is made of a Paleozoic basement with a Paleozoic and Mesozoic carbonate cover overlain by Jurassic ophiolite obducted toward the end of the Jurassic (Jacobshagen, 1986).

Below the Pelagonian Zone is the Cycladic Blueschist Unit, which is generally considered part of the Pindos Zone (Jolivet and Brun, 2010; Ring et al., 2010). The Cycladic Blueschist Unit is a continental unit with an Eocene-Oligocene flysch (Özer et al., 2001). The major tectonic members of the Cycladic Blueschist Unit are in decending order: (i) A melange-like assemblage of ophiolitic rocks and garnet-mica schist embedded in a serpentinitic and shaly matrix (Ring et al., 1999). (ii) 


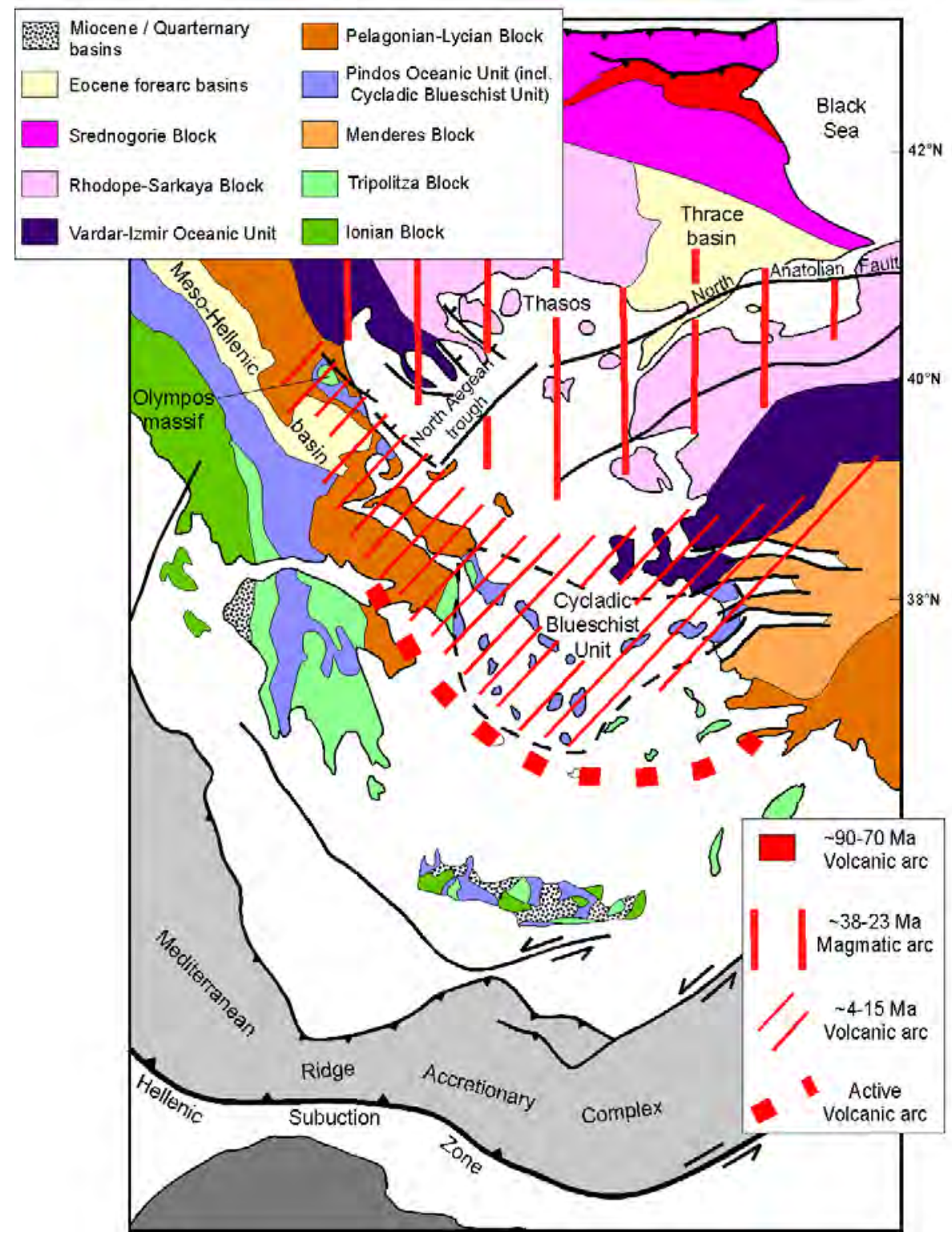

Figure 3 - Map of Hellenide-Anatolide orogen in the Aegean Sea - west Turkey transect. Simplified tectonic map of the Aegean region showing the main tectonic zones above the Hellenic subduction zone. The Mediterranean Ridge represents the modern accretionary wedge that is bounded to the north by a major backthrust system. Red line patterns indicate the positions of subduction-related magmatic-arc rocks from $\sim 38$ Ma to the Recent. The migration of this magmatic arc in the overriding plate mimics the retreat of the Hellenic slab. Also shown (in red) in the north is a volcanic arc related to the subduction of the Vardar-Izmir Oceanic Unit at $\sim 90$ Ma (after Jolivet and Brun, 2010 and Ring et al., 2010).

A shelf sequence composed of marble, metapelite, quartzite and metabasite that has been intruded by Triassic granitoids (Ring et al., 1999). (iii) A Carboniferous basement nappe made up by augengneiss, garnet-mica schist and dolomitic marble (Ring et al., 1999). The various nappes of the 
Cycladic Blueschist Unit have all undergone high-pressure metamorphism at PT conditions of 12$20 \mathrm{kbar}$ and $450-550^{\circ} \mathrm{C}$ between 53 to $30 \mathrm{Ma}$ (see reviews in Jolivet and Brun, 2010 and Ring et al., 2010). Below the Cycladic Blueschist Unit occurs the Tripolitsa Zone. The latter underwent high-pressure metamorphism at $8-14 \mathrm{kbar}$ and $350-450^{\circ} \mathrm{C}$ in windows in the Cyclades and Amorgos and very-low-grade metamorphism in Crete (Jolivet et al., 1996; Shaked et al., 2000). The underlying Ionian Zone is made up by the Plattenkalk and Phyllite-Quartzite units in Crete. At least the Phyllite-Quartzite Unit also shows an increase in high-pressure conditions from Crete (10-12 kbar and $350^{\circ} \mathrm{C}$ in central Crete) to the $\mathrm{W}\left(18 \mathrm{kbar}\right.$ and $\left.400^{\circ} \mathrm{C}\right)$ and $\mathrm{N}\left(>13 \mathrm{kbar}\right.$ and $500-600^{\circ} \mathrm{C}$ in Amorgos) (Rosenbaum et al., 2007). The entire nappe pile has been thrust over the East Mediterranean Accretionary Complex, which started to from at $19 \mathrm{Ma}$ and is being underthrust beneath Crete as the leading edge of the overriding plate.

In summary, the various units below the suture zone in the Aegean transect shows evidence for sustained high-pressure metamorphism. Jolivet and Brun (2010) and Ring et al. (2010) showed that the age for this metamorphism becomes younger from north to south towards lower structural units and reflects stages of the southward retreat of the subducting Hellenic slab.

\subsubsection{Anatolide Belt}

The overall structure of the Anatolide Belt of west Turkey is that of a dome-shaped nappe pile (Sengör et al., 1984). The non- to weakly metamorphosed Lycian Nappes represent a Mesozoic carbonate platform that makes up the highest tectonic unit below the suture zone. Below the Lycian Nappes follows the high-pressure metamorphosed continental Tavşanl1-Afyon-Ören Unit, with a Late Cretaceous (70-60 Ma) age for the high-pressure overprint (Sherlock et al., 1999). The Tavşanl1-Afyon-Ören Unit is underlain by the Cycladic Blueschist Unit, the latter of which has a similar tectonometamorphic history as in the Aegean Sea region (Gessner et al., 2011) and has been metamorphosed at high-pressure conditions around 42-40 Ma (Candan et al., 1997). The Cycladic Blueschist Unit in west Turkey has a lower sedimentary unit, the Dilek Nappe, composed of a shelf sequence comprising metapelite, quarzite, metabasite lenses and metabauxite-bearing marble. The Dilek Nape is overlain by the Selcuk melange, an assemblage of ophiolitic rocks embedded in a serpentinitic and shaly matrix. The Cycladic Blueschist Unit in west Turkey rests along the out-of-sequence Cyclades-Menderes Thrust above the Menderes Nappes (Gessner et al., 2013). The Menderes Nappes consists of four individual nappes, which, and this is an important point of our review, do not show any signs for a high-pressure overprint (Ring et al., 2001). It is important to note that detailed studies by various groups has demonstrated that the entire sequence below the two magneisocarpholite-kyanite-chloritoid bearing rocks does not show any relics for a high pressure overprint (Regnier et al., 2003), indicating that most probably the entire Menderes Nappes did not undergo high-pressure metamorphism.

In descending order the Menderes Nappes consist of: (1) The Selimiye Nappe containing Paleozoic sequence of schist, marble and quartzite. (2) The Çine Nappe made up by a Pan-African basement unit consisting of metagranite, augengneiss, metabasite and metapelite. Intrusion of most of the magmatic rocks took place at the Precambrian/Cambrian boundary and in part cut the penetrative amphibolite-facies tectonometamorphic fabric in the Çine Nappe (Gessner et al., 2001a). (3) The Bozdağ Nappe consisting of metapelite and quartzofeldspathic rock, which have been intruded by Pan-African and Triassic granitoids. Especially the Triassic granitoids cut the penetrative amphibolite-grade tectonometamorphic fabric in the Bozdağ Nappe. (4) The greenschist-facies Bayındir Nappe at the base containing schist and marble, the latter of which has Late Cretaceous rudists (Özer et al., 2001). The above described nappe pile has been thrust in a southerly direction onto the non-metamorphosed Mesozoic Bey Dağları carbonate platform in Miocene times (van Hinsbergen, 2010).

We stress, that the architecture of the Hellenide Orogen and the Anatolide Belt is strikingly different. As discussed in Ring et al. (1999), the Dilek nappe and the Selcuk melange can be correlated with nappes of the shelf sequence and the overlying ophiolitic melange of the Cycladic Blueschist

$\underline{\text { XLVII. No } 2-629}$ 
Unit in the Aegean and therefore might serve as a vertical marker. The intrusion of Triassic granitoids, which are interpreted to be related to the final closure of Paleotethys to the north (Sengör et al. 1984), into this shelf sequence indicates that it was the northern passive margin of Tethys. The Carboniferous basement of the Cycladic Blueschist Unit underlies this marker and has no counterpart in western Turkey. In contrast, some of the Menderes Nappes have a Pan-African basement and underlie this marker. This demonstrates that both regions belong to different crustal provinces. Therefore, both regions had different lithospheres before the onset of orogeny, and it is conceivable, and actually very likely, that the mantle components of the different lithospheres were different as well. Because only Adria had an anomalously heavy lithospheric mantle, pronounced rollback and sustained high-pressure metamorphism characterizes the Aegean Sea region. In west Turkey, the lighter lithosphere of Anatolia halted subduction and the Menderes Nappes escaped sustained high-pressure metamorphism.

\subsection{Topography}

The differences in orogenic structure are reflected in a different morphologic development of both regions (Gessner et al., 2013). The Hellenide Orogen in the Aegean is largely under water and the islands either represent updomed footwalls of metamorphic core complexes or are horst structures due to post-core-complex high-angle normal faulting. The highest mountain peaks are on either side of the Aegean Sea basin (Mt. Ochi, 1394m, in southeast Evia and Kerkis, 1414m, in west Samos). Within the central Aegean peaks rarely reach 1000m (e.g. Mt. Zas in Naxos, 999m). The islands are separated from each other by Miocene to Recent graben structures with water depths of the order of $1000-2000 \mathrm{~m}$.

In contrast, the entire Anatolide Belt of west Turkey is emergent. The topographic evolution shows a two-stage history. After a first phase of lithospheric scale extension at the Oligocene/Miocene boundary (for details see below), an areally extensive erosion surface formed by mid-Miocene times (Yilmaz et al., 2000). This erosion surface shows that an orogenic plateau of unknown elevation had formed in west Turkey. The mid-Miocene erosion surface has then been significantly deformed from the Pliocene to the Recent by fragmentation of the plateau by the Kuzey and Güney detachment systems of the Central Menderes metamorphic core complex (Gessner et al., 2001b). In the footwalls of the two detachment systems a mountainous topography with peak elevations $>2000 \mathrm{~m}$ developed. It is likely that the topography and high elevation are the incised remains of the former plateau.

\subsection{Magmatic Evolution}

Most plutonic and volcanic rocks in the Aegean have enriched isotope signatures, which together with pronounced enrichment of incompatible elements, indicate mantle refertilization by a subduction component similar to continent-derived sediments subducted at the present Hellenic Trench (Siebel and Altherr, 2002) and reflect a history of melting processes above the long-lived southward retreating Hellenic subduction zone. The transfer of heat and juvenile melts from the mantle varied probably in response to episodic roll-back of the subducting lithospheric slab, as suggested by punctuated crystallisation age spectra within and among individual granitoid plutons. Detailed studies on the silicic plutonic rocks in the central Aegean document an episodic crystallisation history from 11 to $17 \mathrm{Ma}$, with peraluminous (S-type) granitoids systematically older than closely associated metaluminous (I-type) granitoids (Bolhar et al., 2010).

Post-collisional magmatism in western Anatolia began in the Eocene, and propagated from north to south (Dilek and Altunkaynak, 2007). The youngest plutonic rocks in the Menderes Massif are the Salihli and Turgutlu granodiorites with ages of 16-15 Ma (Glodny and Hetzel, 2007). The two granodiorites have a subduction zone geochemical signature, which may have been inherited from earlier subduction events in the region. During the evolution of the Eocene and Oligo-Miocene volcano-plutonic rocks, this subduction influence decreased and crustal contamination increased through time. In the early Miocene, alkaline bimodal magmatic rocks became more prominent (Dilek and Altunkaynak, 2007). The final phase of magmatism produced late Miocene to Quater-

$\underline{\text { XLVII, No } 2-630}$ 
nary alkaline to super-alkaline volcanic rocks with progressively more potassic compositions. Asthenospheric upwelling caused by partial delamination of the lithospheric root beneath the western Anatolian orogenic belt was likely responsible for the melt evolution of these alkaline volcanics (Dilek and Altunkaynak, 2007).

The alkaline basaltic activity since the Miocene was temporally distinct from the older subductionrelated magmatism. Most of these alkaline volcanics occurs along the Aegean Sea / Turkish coastline (Agostini et al., 2007). The intraplate character of this alkaline association indicates that the mantle wedge, previously metasomatized by slab-derived material, was replaced by the upwelling of asthenospheric mantle as a result of rupturing of the downgoing slab.

\subsection{Lithospheric Structure}

Crustal thickness in the Aegean Sea region is variable. In the Cyclades it is around $30 \mathrm{~km}$ and towards the south the crust thins to about $15 \mathrm{~km}$ in the Cretan Sea south of the present volcanic arc. Underneath Crete the crust thickens again to some $40-50 \mathrm{~km}$ in the west and $30 \mathrm{~km}$ in eastern Crete (Knapmeier and Harjes, 2000). The thick crust underneath western Crete is due to underthrusting of sediments; this underplating process diminishes to the east and eventually stops in the southeast Aegean.

The results show a general trend of westward crustal thinning from $36 \mathrm{~km}$ in central Anatolia to 28-30 km in the central Menderes Massif to $25 \mathrm{~km}$ beneath the Aegean Sea. The results also indicate that crustal thinning in the Aegean is not uniform in the N-S extensional direction. The crust is thinner in the central Menderes Massif (28-30 km of crustal thicknesses) and the Cycladic Massif $(25-26 \mathrm{~km})$ than in surrounding regions where crustal thicknesses are $32-34 \mathrm{~km}$.

The Aegean is 'underthrust' by Eocene and younger nappes (van Hinsbergen et al., 2005), all of which record high-pressure metamorphism at depth of 40-70 km (Ring and Layer, 2003). The entire former lower crust and the lithospheric mantle section of the incoming Adriatic plate has been subducted.

The lithosphere of Adria pinches out the east (Figure 2) and this appears to be marked by a lack of subduction-related seismicity to the east of Crete (Knapmeier and Harjes, 2000), the reduced crustal thickness in eastern Crete and the shallowing and disappearance of the Pliny and Strabo furrows in the Rhodos basin (Figures. 1, 3).

The crustal thickness of the Anatolide Belt in west Turkey is of the order of $40 \mathrm{~km}$ and thus significantly thicker than in the Aegean Sea region (Makris and Stobbe, 1984). Van Hinsbergen et al. (2010) argue that the Anatolide Belt of west Turkey is still underlain by its own continental lower crust. In contrast to the Aegean Sea region, there is no evidence that the Anatolide Belt is 'underplated' by Eocene and younger nappes (Ring et al., 1999; van Hinsbergen, 2010). Based on tomographic images and a new gravity model of the Moho from west Turkey van Hinsbergen et al. (2010) and Gessner et al. (2013) further argue that the Anatolide Belt does not have a mantle lithosphere, but is instead overlying asthenosphere directly. Such a view is supported by geophysical data of Meier et al. (2007) showing an 'asthenospheric window' beneath west Turkey. Van Hinsbergen (2010) suggests that the delamination of the lithospheric mantle started at about 45 or so to the north of the Anatolide belt and continued until about $35 \mathrm{Ma}$, for the slab to be able to accommodate ongoing Africa-Europe convergence. However, Prelevic et al. (2010) showed that magma compositions in west Anatolia is alkaline bimodal since the early Miocene, and that magmatic activity progressed from north to south, and volcanic rocks became higher in potassium towards the west. There is also isotopic evidence for a drastic shallowing of the source region of mafic magma since the early Miocene (Prelevic et al., 2010). These data strongly support the hypotheses that the removal of the lithospheric mantle below west Anatolia started in the early Miocene. The development of the mid Miocene erosion surface on the plateau may have either been caused by shallowing of subduction or is due to dynamic topography caused by the delamination of the lithospheric mantle. 
Mantle tomography images suggest a tear in the downgoing slab in the west of Turkey (de Brooder et al., 1999). Such a tear would explain the drastic differences in lithospheric structure and tectonic evolution between the Aegean Sea and west Turkey. However, it is not known when this tear formed. Ring et al. (2010) proposed that it formed in the early Miocene. Berk Biryol et al. (2011) interpreted a new gravity anomaly and crustal thickness models to support a mantle-scale discontinuity across the Aegean coastline of Anatolia. Gessner et al. (2013) suggest an early Miocene age for this discontinuity.

\section{Discussion}

\subsection{Differential extension}

Fission track data (Figure 4, 5) reflect marked differences in the mid/late Miocene cooling history between the Aegean Sea region and western Anatolia (Ring et al., 2010). In the central Aegean, ongoing extension above the southward retreating Hellenic subduction zone was aided in the mid Miocene by the southward migration of the magmatic arc into the Cyclades region and the central Aegean underwent a major phase of lithospheric extension between about 15-8 Ma (Ring et al., 2010). At the same time in the mid Miocene a peneplain associated with plateau formation occurred in west Anatolia (Yilmaz et al., 2000). The regional cooling ages as discussed in Ring et al. (2003) suggest that extensional deformation largely ceased during that time in west Anatolia.

There is a ridge of old fission track ages along the west Anatolian coastline, which is interpreted to reflect a lack of Miocene detachment faults along the west Anatolian coastline. The Menderes detachments taper out to the west while the Aegean detachments have not laterally propagated into west Anatolia (Figure 3). In map view this geometry defines two spatially separated extension provinces divided by the ridge of old fission track cooling ages. A simple 3D elastic model of two simultaneously moving laterally tapering detachment fault systems should cause extension perpendicular to the slip directions of the two detachment systems (Bernhard Grasemann, written communication, 2011). Such E-W extension has in fact been reported from Samos Island in the easternmost Aegean right at the Turkish coastline by Ring et al. (1999). ZFT cooling ages indicate that $\mathrm{E}-\mathrm{W}$ extension commenced $\geq 20 \mathrm{Ma}$ (Ring et al., 2010).

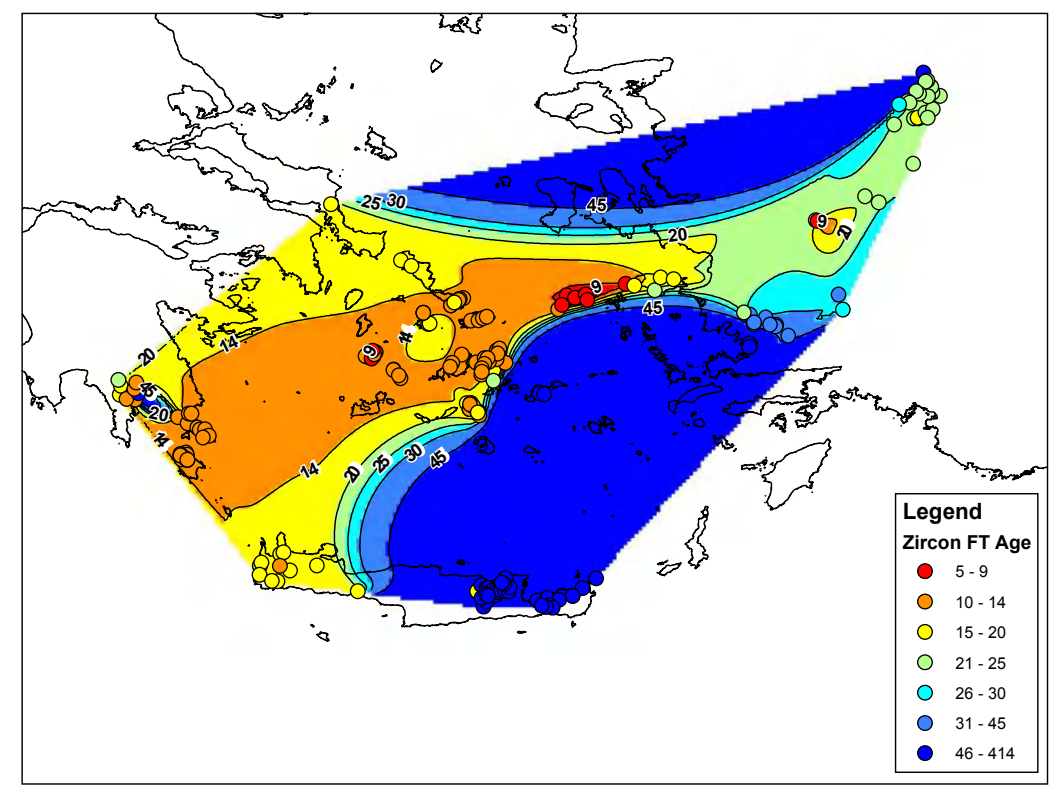

Figure 4 - Contoured map showing zircon fission track ages in the Aegean Sea region and adjacent west Turkey.

$\underline{\text { XLVII, No } 2-632}$ 


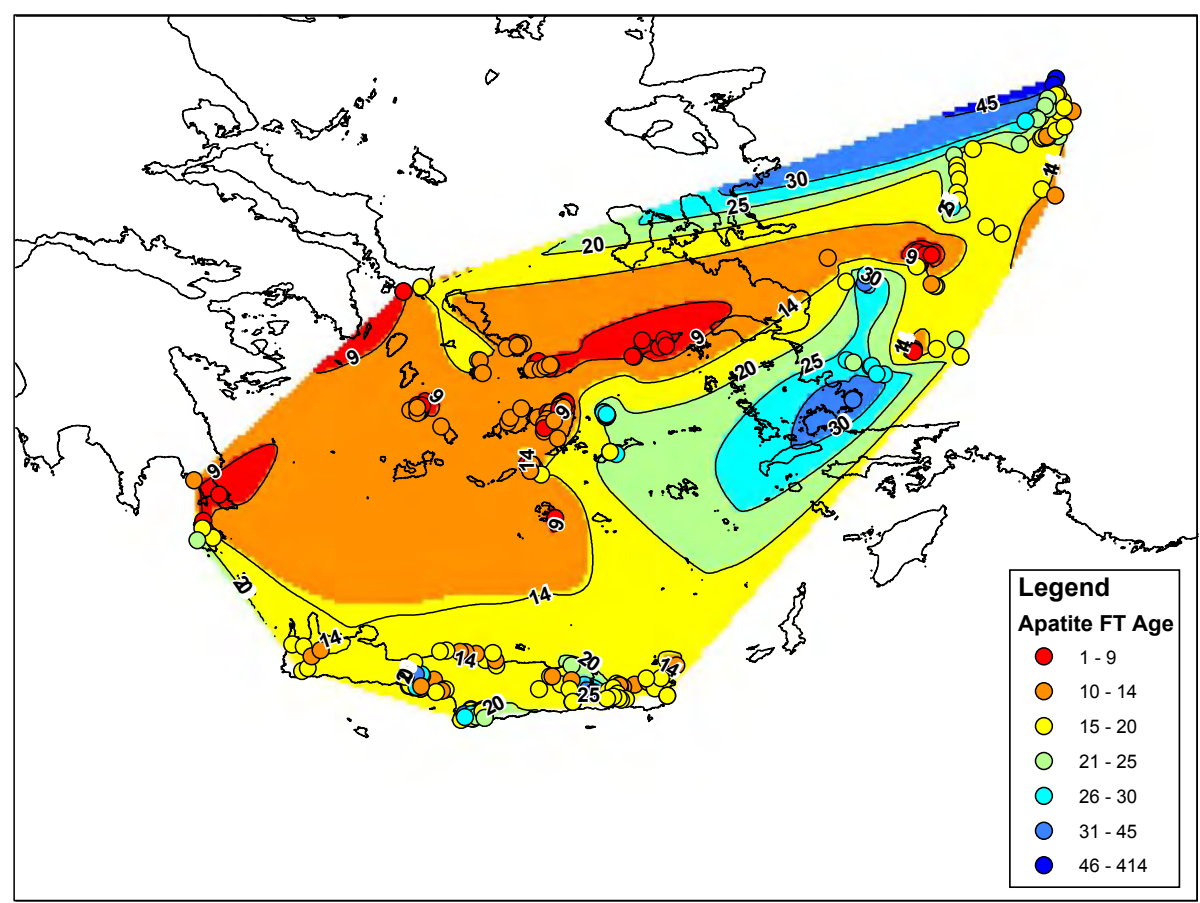

Figure 5 - Contoured map showing apatite fission track ages in the Aegean Sea region and adjacent west Turkey. Note 'ridge' of fairly old fission track ages in west Turkey.

Because extension in the Aegean Sea is greater by a factor of $>3$ than in west Anatolia, the detachment faults caused differential extension since the onset of extension at the Oligocene/Miocene boundary. The onset of E-W extension in Samos Island coincides well with the onset of differential extension across the Aegean and west Anatolia. The region that accommodated this differential extension coincides with the ridge of old FT ages.

\subsection{Sinistral Wrench Corridor - West Anatolia Transfer Zone}

The most prominent extensional structures in western Turkey are Miocene to recent E-W trending graben. Two of these grabens - the Gediz graben in the north and the Büyük Menderes graben in the south - delimit the Central Menderes Metamorphic Core Complex. The area north of the Central Menderes Metamorphic Core Complex - the northern Menderes Massif - displays a pattern of NE-striking basins bounded by basement domains. South of the Central Menderes Metamorphic Core Complex similar basins strike NNW rather than NE. Both the NE- and the NNW-striking basins appear to have formed contemporary with early manifestations of the E-W graben, but are much shallower.

We propose that shearing during sinistral strike slip has caused transtensional folding with a wavelength of tens of kilometers in the Menderes Massif. This large-scale near-simple-shear deformation accommodates a gradient in crustal extension forced by pronounced retreat of the Hellenic subduction zone since the earliest Miocene, which appears to be spatially restricted to the Aegean Sea region causing the curvature of the Hellenic slab. Folding caused uplift of basement in the anticlines, while providing accommodation space for the Miocene basins in the synclines. Transtensional folding is followed (accompanied?) by the tectonic denudation of the Central Menderes Metamorphic Core Complex, which also appears to have accommodated higher extensional strain towards its western limit. Our model provides an explanation for the geometry and timing of Neogene basins in the Menderes Massif. 

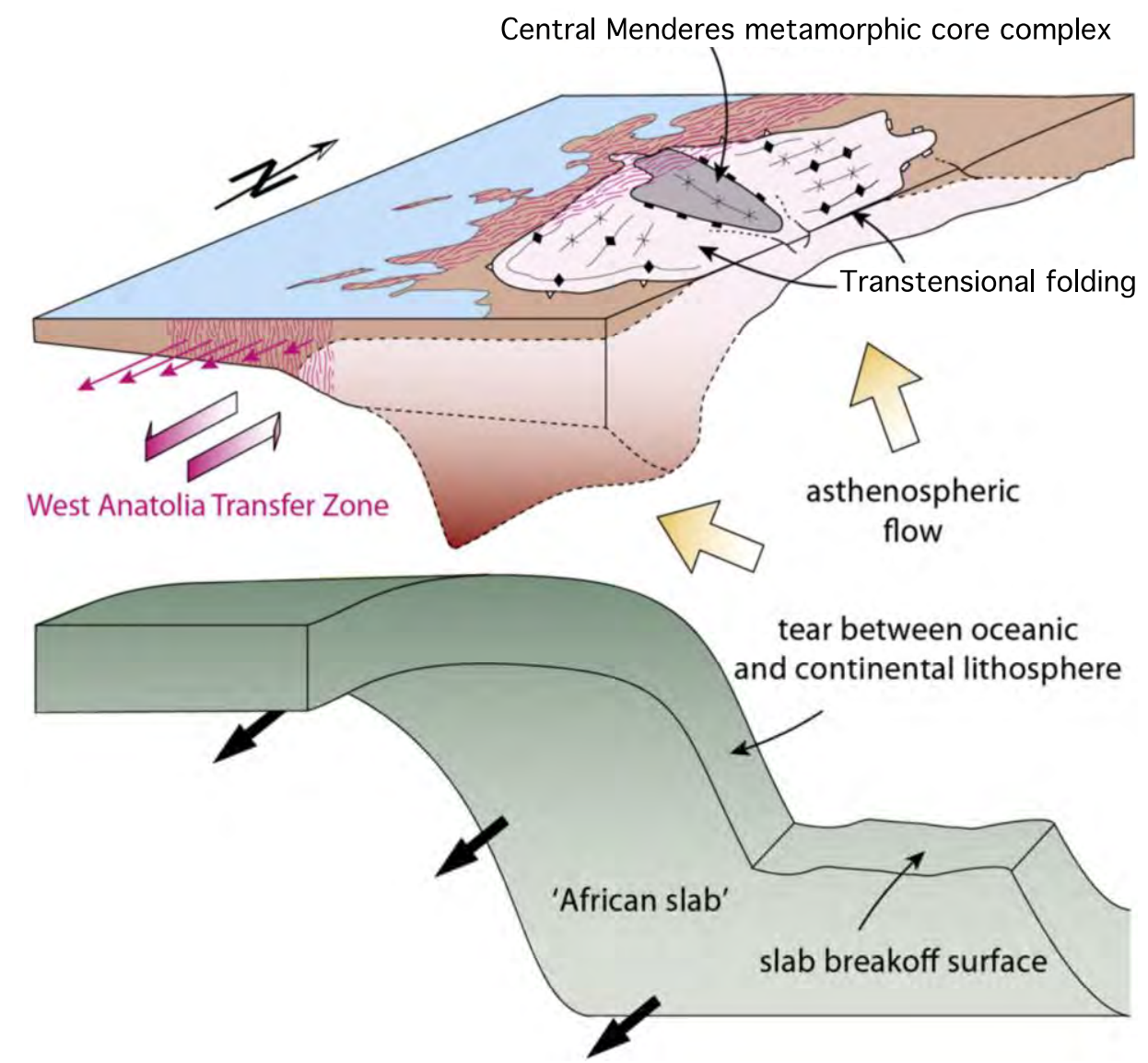

Figure 6 - Conceptual model of the present slab dynamics at the Aegean/Turkish border. The retreat of the Aegean slab with its vertical edge maintains a transtensional situation that controls diffuse brittle deformation along the coast and inboard of the Aegean.

\subsection{Tectonic interpretation}

Gessner et al. (2013) showed that there are marked differences in Bouguer gravity data between the Aegean Sea region and western Anatolia. The gravity data define a N-S oriented boundary between a gravity high in the Aegean and lower gravity values below west Anatolia. Seismic velocity anomalies show a sharp vertical boundary between the fast, cold and dense African slab below the Aegean and a slow, hot and buoyant asthenospheric region below the Menderes Massif, the West Anatolia Transfer Zone.

Recent reviews of Aegean tectonics by Jolivet and Brun (2010) and Ring et al. (2010) highlight the common opinion that the slab of the downgoing Adria/Africa slab reached the $660 \mathrm{~km}$ discontinuity at about the Oligocene/Miocene boundary, then was draped over this discontinuity causing a dramatic phase of rollback. This pronounced rollback caused widespread extension in the Aegean Sea region and may have also triggered extension in adjacent west Anatolia. The very different lithosphere of the Adriatic and Anatolian slab behaved very differently. The more buoyant Anatolian slab did not roll back. This differential lithospheric behaviour caused a tear in the downgoing slab along the boundary of the different lithosphere along the west Anatolian coastline.

The slab tear allowed the asthenosphere of the incoming African slab to flow lateral around the retreating slab and aided rollback resulting in faster extension in the Aegean Sea region. We think that enhanced rollback/extension is basically reflected by the widespread fission track cooling ages of 15 to $8 \mathrm{Ma}$ in the central Aegean.

XLVII. No $2-634$ 
The subduction of continental material in west Anatolia resulted in the major along-strike differences. Subduction of continental material commonly results in delamination and/or rupture of the oceanic slab (Sacks, 1990), which detaches and sinks into the mantle leaving behind positively buoyant continental material that rebounds isostatically (Milsom, 1986) resulting in rapid surface uplift above the rebounding slab. The rebound was probably enhanced by the lateral flow of the asthenosphere around the retreating Adriatic slab. This flow may indeed have heated the lithosphere of west Anatolia making it thermally and mechanically unstable more unstable. The rebound ultimately caused the Miocene Plateau in west Anatolia. The asthenospheric flow under west Anatolia is also capable of explaining the lamporite geochemistry associated with plateau formation.

The tectonic model argued for here calls for very different evolutions of the Aegean Sea region and west Anatolia. The rollback of the slab in the Aegean Sea ultimately created the free space for the westward extrusion of Anatolia commencing in the late Miocene and propagating into west Anatolia.

\section{References}

Agostini S., Doglioni C., Innocenti F., Manetti P., Tonarini S. and Savaşçin M.Y. 2007. The transition from subduction-related to intraplate Neogene magmatism in the Western Anatolia and Aegean area, Special Paper of the Geological Society of America, 418, 1-15.

Berk Biryol C., Beck S.L., Zandt G. and Özacar A.A. 2011. Segmented African lithosphere beneath the Anatolian region inferred from teleseismic P-wave tomography, Geophy. J. Inter., 184, 1037-1057.

Bolhar R., Ring U. and Allen C.M. 2010. An integrated zircon geochronological and geochemical investigation into the Miocene plutonic evolution of the Cyclades, Aegean Sea, Greece: Part 1 - Geochronology, Contributions Mineralogy Petrology, 160, 719-742, DOI: 10.1007/s00410-010-0504-4.

Candan O., Dora O.Ö., Oberhänsli R., Oelsner F. and Dürr S. 1997. Blueschist relics in the Mesozoic cover series of the Menderes Massif and correlations with Samos Island, Cyclades, Schweiz.Mineralog. Petrograph. Mitt., 77, 95-99.

de Boorder H., Spakman W., White S.H. and Wortel M.J.R.1998. Late Cenozoic mineralization, orogenic collapse and slab detachment in the European Alpine Belt, Earth Planet. Sci. Lett., 164, 569-575.

Dilek Y. and Altunkaynak S.2007. Cenozoic crustal evolution and mantle dynamics of postcollisional magmatism in western Anatolia, Intern. Geol. Rev., 49, 431-453.

Gessner K., Ring U., Passchier C.W. and Gungor T.2001a. How to resist subduction: evidence for large-scale out-of-sequence thrusting during Eocene collision in western Turkey, J. Geol. Soc., 158, 769-784.

Gessner K., Ring U., Johnson C., Hetzel R., Passchier C.W. and Gungor T. 2001b. An active bivergent rolling-hinge detachment system: Central Menderes metamorphic core complex in western Turkey, Geology, 29, 611-614.

Gessner K., Ring U. and Güngör T. 2011. Field guide to Samos and the Menderes Massif; alongstrike variations in the Mediterranean Tethyan Orogen, GSA field trip guide 22.

Gessner K., Gallarado L., Markwitz V., Ring U. and Thomson S.N. 2013. What caused the denudation of the Menderes Massif: Review of crustal evolution, lithospheric structure, and dynamic topography in southwest Turkey, Gondwana Research, 24, 243-273.

Glodny J.and Hetzel R. 2007. Precise U-Pb ages of syn-extensional Miocene intrusions in the central Menderes Massif, western Turkey, Geol. Mag., 144, 235-246.

Houseman G.A., McKenzie D.P. and Molnar P. 1981. Convective instability of a thickened boundary layer and its relevance for the thermal evolution of continental convergent belts, J. Geophys. Res., 86, 6115-6132.

Jacobshagen V.1986. Geologie von Griechenland, Borntraeger, Berlin.

XLVII. No 2-635 
Jolivet L., Goffé B., Monié P., Truffert-Luxey C. and Bonneau M. 1996. Miocene detachment in Crete and exhumation P-T-t paths of high-pressure metamorphic rocks, Tectonics, 15, 1129-1153.

Jolivet L. and Brun J.P. 2010. Cenozoic geodynamic evolution of the Aegean, Intern. J. Earth Sci., 99, 109-138.

Knapmeyer M. and Harjes H.P. 2000. Imaging crustal discontinuities and the downgoing slab beneath western Crete, Geophys. J. Internat., 143, 1-22.

Makris J. and Stobbe C. 1984. Physical properties and state of the crust and upper mantle of the Eastern Mediterranean Sea deduced from geophysical data, Marine Geol., 55, 347-363.

Özer S., Sözbilir H., Özkar I., Toker V. and Sari B. 2001. Stratigraphy of Upper CretaceousPalaeogene sequences in the southern and eastern Menderes Massif (western Turkey), Intern. J. Earth Sci., 89, 852-866.

Prelevic D., Akal C., Foley S.F., Romer R.L., Stracke A. and van den Bogaard P.2010a. Postcollisionsl mantle dynamics of an orogenic lithosphere: lamproitic mafic rocks from SW Anatolia, Turkey, Tectonic Crossroads: Evolving Orogens of Eurasia-Africa-Arabia, Ankara, pp. 18-12.

Regnier J.L., Ring U., Passchier C.W., Gessner K. and Gungor T. 2003. Contrasting metamorphic evolution of metasedimentary rocks from the Cine and Selimiye nappes in the Anatolide belt, western Turkey, J. Metam. Geol., 21, 699-721.

Ring U., Gessner K., Gungor T. and Passchier C.W. 1999. The Menderes Massif of western Turkey and the Cycladic Massif in the Aegean - do they really correlate?, J. Geol. Soc., 156, 36.

Ring U. and Layer P.W. 2003. High-pressure metamorphism in the Aegean, eastern Mediterranean: Underplating and exhumation from the Late Cretaceous until the Miocene to Recent above the retreating Hellenic subduction zone, Tectonics, 22 TC001350.

Ring U., Glodny J., Will T. and Thomson S.N.2010. The Hellenic subduction system: Highpressure metamorphism, exhumation, normal faulting and large-scale extension, Annual Rev. Earth Planet. Sci. 38, 45-76.

Robertson A.H.F., Clift P.D., Degnan P.J. and Jones G.1991. Palaeogeographic and palaeotectonic evolution of the Eastern Mediterranean Neotethys, Palaeogeo., Palaeoclimat., Palaeoecol. 87, 289-343.

Rosenbaum G., Ring U. and Kühn A. 2007. Tectono-metamorphic evolution of high-pressure rocks from the island of Amorgos (Central Aegean, Greece), Journal of Geological Society London, 164, 425-438.

Royden L.H. 1993. Evolution of retreating subduction boundaries formed during continental collision, Tectonics, 12, 629-638.

Sengör A.M.C., Satir M. and Akkök R.1984. Timing of the tectonic events in the Menderes massif, western Turkey: implications for tectonic evolution and evidence for Pan-African basement in Turkey, Tectonics 3, 693-707.

Sherlock S., Kelley S., Inger S., Harris N., Okay A. 1999. 40Ar-39Ar and Rb-Sr geochronology of high-pressure metamorphism and exhumation history of the Tavsanli Zone, NW Turkey, Contrib. Mineral. Petrol., 137, 46-58.

van Hinsbergen D.J.J., Hafkenscheid E., Spakman W., Meulenkamp J.E. and Wortel R. 2005. Nappe stacking resulting from continental lithosphere below subduction of oceanic and Greece, Geology, 33, 325-328.

van Hinsbergen D.J.J., Kaymakci N., Spakman W. and Torsvik T.H. 2010. Reconciling the geological history of western Turkey with plate circuits and mantle tomography, Earth Planet. Sci. Lett., 297, 674-686.

Yilmaz Y., Genç S.C., Gürer F., Bozcu M., Karacik Z., Altunkayak S.and Elmas A. 2000. When did the western Anatolian grabens begin to develop? In: Bozkurt, E., Winchester, J.A., Piper, J.D.A. (Eds.), Tectonics and Magmatism in Turkey and the surrounding area, pp. 353384.

$\underline{\text { XLVII, No } 2-636}$ 